Meta

Journal des traducteurs

Translators' Journal

\title{
Cultural Presuppositions and Misreadings
}

\section{Ke Ping}

Volume 44, numéro 1, mars 1999

Théorie et pratique de la traduction en Chine

The Theory and Practice of Translation in China

URI : https://id.erudit.org/iderudit/003296ar

DOI : https://doi.org/10.7202/003296ar

Aller au sommaire du numéro

Éditeur(s)

Les Presses de l'Université de Montréal

ISSN

0026-0452 (imprimé)

1492-1421 (numérique)

Découvrir la revue

Citer cet article

Ping, K. (1999). Cultural Presuppositions and Misreadings. Meta, 44(1), 133-143.

https://doi.org/10.7202/003296ar
Résumé de l'article

Parmi les nombreux facteurs susceptibles de causer une mauvaise interprétation, les présuppositions culturelles demandent au traducteur une attention particulière car elles peuvent modifier l'interprétation du texte source de façon substantielle et systématique sans qu'il en ait conscience. Cet article fait ressortir les relations entre les présuppositions culturelles et la mauvaise interprétation en traduction. L'auteur examine les éléments importants des quatre sous-systèmes culturels et voit comment ils peuvent développer des présuppositions affectant par inadvertance le décodage du message source par le traducteur. 


\title{
Cultural Presuppositions and Misreadings
}

\author{
ke ping \\ Nanjing University, \\ Nanjing, China
}

\begin{abstract}
RÉSUMÉ
Parmi les nombreux facteurs susceptibles de causer une mauvaise interprétation, les présuppositions culturelles demandent au traducteur une attention particulière car elles peuvent modifier l'interprétation du texte source de façon substantielle et systématique sans qu'il en ait conscience. Cet article fait ressortir les relations entre les présuppositions culturelles et la mauvaise interprétation en traduction. L'auteur examine les éléments importants des quatre sous-systèmes culturels et voit comment ils peuvent développer des présuppositions affectant par inadvertance le décodage du message source par le traducteur.
\end{abstract}

\begin{abstract}
Of the many factors that may lead to misreadings in translation, cultural presuppositions merit special attention from translators because they can substantially and systematically affect their interpretation of facts and events in the source text without their even knowing it. This paper attempts to pinpoint the relationship between cultural presuppositions and translational misreadings. The author considers major elements in the four subsystems of culture and examines how these elements help breed presuppositions that inadvertently affect the translator's decoding of the original message.
\end{abstract}

No man ever looks at the world with pristine eyes. He sees it edited by a definite set of customs and institutions and ways of thinking.

Ruth Benedict (1959: 2)

Misreadings have occured in translations of every era. Since translation consists, at its most basic level, in "understanding and making others understand," a misreading by the translator will distort the source message and result in some form or another of communication breakdown between the source writer and the target reader.

Misreadings in translation are often caused by a translator's presuppositions about the reality of the source language community. These presuppositions are usually culturally-derived and deserve the special attention of the translator. This paper looks at how cultural presuppositions work to produce misreadings in translation.

Philosophically, a presupposition refers to a logically necessary condition which must be satisfied for a particular state of affairs to be possible, e.g. the uniformity of nature is a presupposition of the rationality of inductive reasoning; memory is a presupposition of our having a concept of the past. Kant's ethical theory of the "categorical imperative" is an account of the presuppositions of a particularly rigourous form of Protestant morality (Bullock \& Stallybrass 1977: 495).

"Cultural presupposition," in the present study, refers to underlying assumptions, beliefs, and ideas that are culturally rooted, widespread, but rarely if ever described or 
defined because they seem so basic and obvious as not to require verbal formulation. For example, truth in the Bible is presupposed to be essentially about moral behaviour rather than an abstract definition of reality or being; likewise, wisdom is seen as the ability to decide moral and human issues with justice, rather than the intellectual capacity to formulate philosophical questions and create cogent systems. The symbols of light and darkness are not related in the Bible to knowledge and ignorance, but to deliverance from or enslavement to evil. And "to know" the Lord, sin, or deliverance, is not to "know about" then but to experience them (Nida and Reyburn 1981: 14-16).

The term "culture" is used in this paper in its anthropological sense. The first important anthropological definition of culture was presented by Sir Edward Tylor in Primitive Cultures (1871). He defines culture as "that complex whole which includes knowledge, belief, art, law, morals, customs and any other capabilities and habits acquired by man as a member of society" (quot. in Bock 1979: 13-14). Tylor's definition continues to provide the basis of most modern anthropological conceptions of culture.

Most anthropologists agree on the following features of culture:

(1) culture is socially acquired instead of biologically transmitted;

(2) culture is shared among the members of a community rather than being unique to an individual;

(3) culture is symbolic. Symbolizing means assigning to entities and events meanings which are external to them and which cannot be grasped alone. Language is the most typical symbolic system within culture;

(4) culture is integrated. Each aspect of culture is tied in with all other aspects.

Culture is normally regarded as comprising, with some slight variations, the following four sub-systems:

(1) Techno-economic System:

ecology (flora, fauna, climate, etc.) $;^{1}$

means of production, exchange, and distribution of goods;

crafts, technology, and science;

artifacts.

(2) Social System:

social classes and groups;

kinship system (typology, sex and marriage, procreation and paternity, size of family, etc.);

politics and law;

education;

sports and entertainment;

customs;

general history. ${ }^{2}$

(3) Ideational System:

cosmology;

religion;

magic and witchcraft;

folklore; 
artistic creations as images;

values (moral, aesthetic, etc.);

cognitive focus and thinking patterns;

ideology.

(4) Linguistic System:

phonology and graphemics;

grammar (morphology and syntax);

semantics and pragmatics.

Each ingredient in these four sub-systems can lead to presuppositions that are fundamentally different from those bred by other cultures, and hence might result in misreading when translation or other forms of communication are conducted across two cultures. In the following section, I will consider some of these culture-bound presuppositions as observed in mistranslated texts.

\section{CULTURAL PRESUPPOSITIONS RELATED TO TECHNO-ECONOMIC SYSTEMS}

At the turn of the 20th century, when Western and Russian literature was first introduced into China on a large scale, "drawing-room" used to be translated into Chinese as tuhua shi (artist's studio). The interior structure of Western-styled houses was, at the time, rather alien to most Chinese, for whom a room with a similar function was called tangwu (the central room or main hall of a house). Tangwu is, however, not a place for guests to withdraw to after dinner, but a room where guests are received and meals are taken. Presupposing that the room in a Western-styled house which functioned as a tangwu ("hall-room") would be referred to as such, the translators did not bother to consult a dictionary to find out what a "drawing-room" really was, and ended up using the wrong Chinese word.

\section{CULTURAL PRESUPPOSITIONS RELATED TO SOCIAL SYSTEMS}

Courtesy expressions reflect the socio-behavioural patterns of a culture. The notion of courtesy seems to be universal, but people from different cultures employ very different expressions to denote courtesy. Traditionally, a Chinese person may greet a friend or acquaintance by asking "Have you had your meal?" or "Where are you going?" A Westerner would, however, say something like "Hello!," "Good morning!," "Nice day, isn't it?" When meeting a friend who has just arrived from a long journey, a Chinese person would conventionally say: "You must have had a tiring journey." The Westerner would ask instead: "Did you have a nice trip?" or "Did you enjoy your trip?"

One principle of information theory states that the greater the probability of an event occurring, the less information a message will contain about it. In language, the more frequently an expression occurs, the less meaningful it becomes. Since courtesy expressions are used very frequently, their meaning is almost exclusively pragmatic. When they are transferred literally into another language on the presupposition that the target language has the same pattern of phatic communication, they may be understood according to their referential meaning and create misunderstanding on the part of the target audience. 


\section{CULTURAL PRESUPPOSITIONS RELATED TO IDEATIONAL SYSTEMS}

Cultural presuppositions related to ideational systems are responsible for the greatest number of translational misreadings because the realities different cultures face differ much less than the ways in which different cultures regard these realities. For instance, both Chinese and Anglo-American culture regard time as a continuum, but when referring to the past and the future in terms of "back" and "ahead," they adopt different starting points. A traditional Chinese stands facing the past, perceiving what just happened as ahead of him and what is yet to come as behind him. A native English speaker, however, assumes the opposite viewpoint. For example:

But we are getting ahead of the story.

Danshi women shuodao gushi de houmian qule. [Lit.: "But we are getting to the back of the story."]

Neglecting this difference in temporal perspective would result in a wrong translation of the following passage, in which the context provides no clues as to the relative earliness or lateness of the time in question:

The first is in the two essays of part II on culture and biological evolution, where the fossil datings given in the original essays have been definitely superseded. The dates have, in general, been moved back in time... [Geertz 1973: preface]

Buddhism played a major role in the evolution of Chinese culture and contributed many expressions to the Chinese language, such as santou liubei ("three hands and six arms.") The Hindu divine trinity is characterized by more heads, arms, and hands than mortal men. Brahma, the Creator of the Universe, has four heads and four hands; Vishnu, the preserver, has four hands; and Siva, God of Destruction and Reproduction, has five heads, four hands, and three eyes. Buddhism remoulded Hindu gods and introduced two patterns for shaping the gods' heads, arms, and hands, one being that of four hands and four eyes, the other being that of three heads and six arms. This pattern entered everyday speech as well as literary language. It is not quite possible for Western audiences to know that "three heads and six arms" in Chinese means superhuman wisdom and power, like the Buddhist gods. To prevent misinterpreting the contextual meaning to the target reader, the phrase is culturally adapted in the following translation:

Tan Zhaodi peng bude ma? Ni shi santou liubei, wo ye gan peng. [Zhou Erfu. Shanghai de Zaochen.]

Is Tan Chao-ti some sacred being that no one dares to offend? But I dare, even if you're a demigod! [Trans. A.C. Barnes]

Different cultures may cling to significantly different presuppositions in terms of values and attitudes. While Western culture prizes the individual, for example, traditional Chinese culture places great emphasis on the group. It is no accident that in the following illustration:

There was nothing mass produced about the school. But if it was individualistic, it also had discipline. [Agatha Christie. Cat Among the Pigeons]

the translator should turn the phrase "mass produced" into the more favourable (and wrong) daliang chu rencai de "producing a large number of talented personnel," 
because in the Chinese mind, group behaviour is socially commended and usually regarded as antithetical to individualistic action, which is often met with suspicion and disapproval.

As the basis of political and economic systems, and a major force shaping modern society, ideology has been at root of many cultural presuppositions that resulted in misreadings of one kind or another. Piotr Kuhiwezak (1990: 125) provides an insightful analysis of the misreading of Milan Kundera's novel The Joke by both the author's own countrymen and Western people. In The Joke (Zert), Kundera tells a love story set in Czechoslovakia in the 1950s and 1960s. The main characters, Ludvik, Kostka, Jaroslav and Helena, are attending university at a time when the country is undergoing significant social and political changes. The crucial event in the novel is a joke, Ludvik plays on his solemn girlfriend $M$ arketa. This joke is nothing more than a postcard in which Ludvik ridicules the political official jargon of the day: "Optimism is the opium of the people! A healthy atmosphere stinks of stupidity! Long live Trotsky!" But what Ludvik considers funny, the rest of the world sees as serious ideological subversion. So everything that follows from this point of the novel results directly from the fact that none of the characters shares Ludvik's sense of humour. And this is exactly why Ludvik, abandoned by his former friends, is expelled from university and sent to a penal military unit in Ostrava. During these long years of hard work in Ostrava he falls in love with Lucie. The relationship is fragile from the start and does not last long because the girl finds it impossible to reconcile her love for Ludvik with sexuality. Years after his release, Ludvik visits his native Moravia where he meets his university colleagues again. The purpose of his trip is to take revenge on those among them who openly contributed to his banishment from the university. H owever, his car efully devised and executed plan misfires because, 15 years after the event, nothing is the same: history has thoroughly erased the once-clear line which separated Ludvik's former enemies from his former friends.

Kundera has been acclaimed as one of the greatest writers of our time. $\mathrm{H}$ is works are almost al ways characterized by an obsessive concern with and persistent deliberation upon the nature of existence and the conditions of modern man's life and spiritual state. Kundera's aim to analyze the actions of ordinary people caught up in situations brought on by their own thoughts and actions. The Joke, which was Kundera's first major work, amply demonstrates this feature of his novels. The author's concern for the universal over the particular in this work may be best illustrated by the following passage, in which Ludvik asks himself about the significance of his own actions, and answers in a way that sums up the main theme of the novelLudvik's quest for rational patterns in life:

Do love stories, apart from happening, being, have something to say? For all my skepticism, I had clung to a few superstitions-the strange conviction, for example, that everything in life that happens to me has a sense beyond itself, means something, that life in its day-to-day events speaks to us about itself so that it gradually reveals a secret, that it takes the form of a rebus whose message must be deciphered, that the stories we live in comprise the mythology of our lives and in that mythology lies the key to truth and mystery. Is it all an illusion? Possibly, even probably, but I can't seem to rid myself of the need to decipher my life continually. [Kundera 1983: 140, Quot. in Kuhiwezak 1990: 127] 
The novel was first published in Czechoslovakia in 1967, one year before the "Prague Spring." In the following two years it was translated into almost all European languages. After the Soviet troops invaded Prague in 1968, the novel was denounced as an anti-socialist tract and was banned, and Kundera himself was forced to leave his country and move to France. In 1969, The Joke's first English translation by David $\mathrm{H}$ amblyn and Oliver Stallybrass was published by M acdonald \& Co. (Publishers) Ltd, London. This version was severely distorted, however, because the translators and publishers understood The Joke as a political fantasy that became reality a few weeks after publication and rewrote it accordingly. Chapters were cut, paste and shifted around, with anything viewed as an insignificant digression or repetition left out, all in order to give the novel, in their view, a proper chronological order. By doing that, they not only destroyed the novel's polyphonic structure, which contributes much to the work's artistic appeal, but, more importantly, gave readers the misguided impression that "the novel could only have been written in a society where Marxism had been taken seriously" (Kuhiwezak 1990: 128). In both Czechoslovakia and the West, The Joke was not taken for what it actually is-a treatise about human experience in general-but was interpreted as a treatise about human experience in a particular socio-historical environment. In both cases, the misreading of Kundera's book arose from political and ideological presuppositions deeply-rooted in the minds of each readership. As Kundera observes, the common folly of ideological presumptuousness (in the Eastern countries) and over-simplification by the press (in theWest) prevented this artistic work from telling its own truth in its own words (Kundera 1991: vii).

Kundera claims that, for many years, he spent more time correcting translations of his novels and chasing down journalists who misrepresented his views than he did writing the novels themselves. His protests eventual ly succeeded in getting the 1969 version withdrawn from the book sellers and most libraries. An edition with the omitted passages reinstated appeared in 1970 as the Penguin Books hardcover edition. In 1983, Faber and Faber published the new American translation of The Joke by M ichael Heim which was approved by Kundera. The story of The Joke therefore has a happy ending, but what it reveals about how conflicting ideologies in the modern world lead to gross misreadings by translators and publishers has persistent significance.

\section{CULTURAL PRESUPPOSITIONS RELATED TO LINGUISTIC SYSTEMS}

Cultural presuppositions may sometimes be traced to the linguistic, especially semantic, structures of a language. The most typical case is where comparable words in different languages carry strikingly different associations. In Chinese, for instance, "vinegar" is often used for jealousy, e.g. chichu ("eat vinegar"- to be jealous). In English, however, the word connotates ill-tempered speech or character, as in "someone's remarks are made with a strong note of vinegar." "Sour" or "vinegary" in English mean "bad-tempered," "peevish" ("a sour mood"), "ill-disposed" or "bitter" ("sour toward one's former associates"). In Chinese, sourness or being sour is associated with pedantry, so a pedantic scholar is often said to be a "sour" one.

In extreme cases, deep-rooted cultural presuppositions and dogmatically held cultural values may even lead the translator to purposefully misrepresent the source 
message. This occured in some Chinese translations of Buddhist scriptures. Chinese Buddhism is in many ways quite different from Hindu Buddhism, although Chinese Buddhists, especially priests, all claim particular sutras as the foundation of their particular sect's doctrine. Buddhist creed was in large measure sinolized through the translation of the sutras. Such basic notions of Buddhism as anitya (impermanence), anatman (no independent individual existence), and sunyata (emptiness or void) entered Chinese philosophy in altered form to bring them in line with Chinese ideology (Jin 1984: 212).

Chinese values proved an important source of interference with sutra translation, especially those values rooted in Confucianism, which the sutra translators made an effort to accommodate. For instance, the exceptional reverence in Chinese consciousness for one's teachers and superiors led the translator of Fa Hua Qing to arbitrarily rewrite the sentence "An enlightened self (Pratyekabuddha) opened his eyes to the Truth without looking to his master for help (anacaryaka)" into "he listened to the Buddha's law and accepted it as being true," which is just the opposite of the original meaning (Nakamura 1981: 209).

Such cases of deliberate misrepresentation are especially common when sex is involved in the original. Generally speaking, Indians are indifferent about sexual matters. They speak plainly when describing sexual affairs and accept such description in so far as they appear as objective fact. German scholars usually translated the sexual descriptions in Indian literature literally. English scholars often resorted to using Latin or some euphemistic explanation rather than a literal translation. Chinese translators of the sutras were much like these English gentlemen in their equivocation in passages involving sex because educated Chinese, influenced by Confucianism, have a distinct aversion to writings about sex. A Pali text mentions that one of the defilements associated with drinking stimulants is that "those who drink liquor are apt to display their sexual organs." The Chinese translator turned this phrase into "those who drink liquor are apt to become angry" (Nakamura 1981: 260-261). This puritanical attitude toward sex is still apparent today in some translations published in China. The translators of an essay carried in an well-known bilingual Englishlearning magazine published in Beijing, for example, turned the phrase "Hollywood's great sex object of the 1980s" into: "Hollywood's great comedian of the 1980s" (The World of English, 1985, no. 2: 40-41).

The Chinese translation of the title of Milan Kundera's novel, The Unbearable Lightness of Being, is another case where cultural presuppositions interfered with the translator's reading of the original. As the English title suggests, the theme of the novel has a philosophical, even somewhat nihilistic, tinge. But the title of the Chinese version, back-translated, reads The Unbearable Lightness in Life. Replacing the preposition "of" with "in" changes the meaning of the title dramatically: it effaces the metaphysical overtones (which are certainly not so positive and inspiring according to the prevalent ideology of contemporary Chinese society) of the original work. Linguistically, the translators could not possibly have confused the proper meaning of the prepositions "of" and "in." The choice was most probably dictated by cultural considerations.

Translators and teachers of foreign languages need to become fully aware of cultural presuppositions, for two reasons. First, a correct interpretation of the source message relies on an understanding of the relevant features of the source culture. In 
many cases, however, the presuppositions a translator harbours about the source culture may be based upon the realities of his or her own culture. If the source and target cultures differ significantly with respect to the issue at hand, the source message may be wrongly deciphered. This is especially true where linguistic ambiguities are involved, as is illustrated in the following two examples taken from English translations of classic Chinese literature. The first example is a stanza in "Qiyue" (The Seventh M oon), a narrative poem from Shi Jing or the Book of Songs, an anthology of verse dating from the 11th to the 6th century BC. The poem reads as follows:

Qiyue liuhuo, jiuyue shouyi.

Chunri zaiyang, youming canggeng.

Nü zhi yikuang, zun bi weihang, yuan cai rousang.

Chunri chichi, caifan yiyi.

Nü xin shangbei, dai ji gongzi tonggui.

In the seventh month the Fire-star declines,

In the ninth month winter garments are handed out.

Spring days bring us the sun's warmth,

And the orioles sing.

Girls carrying deep baskets

Go along narrow pathways,

Look for young mulberry leaves.

As spring days lengthen,

In crowds they gather the southernwood.

A girl's heart is sick and troubled,

Fearing that she may have to go home with her lord.

Trans. Irving Y. Lo (Wang, Yuexi \& Wang Enbao 1994: 64-65)

This poem depicts the year-long toil of the slaves of the Western Zhou Dynasty. The stanza cited portrays a scene in which a group of slave women carrying baskets sets out on a sunny spring day to gather mulberry leaves and southernwood. But despite the lovely weather, one slave girl feels sad and troubled because she is afraid that the profligate son of her owner might force her to go back home with him later. In an English anthology of Chinese literature (Birch et al. 1980: 24), the last line of the stanza is rendered as:

A girl's heart is sick and sad

Till with her lord she can go home.

This translation must appear rather ridiculous to the Chinese reader because it presents a picture which is exactly contrary to the original one, making it look as if the slave girl could not wait to go home with her lover or husband. Superficially, the mistranslation could be attributed to the ambiguities in the meaning of two words in this line, i.e., dai, which may mean either "almost" or "fear" in this context; and ji, which has two equally tenable senses here: "till" and "with," both of which find explicit expression in the English version. Nevertheless, a Chinese reader, even one unfamiliar with classic Chinese, would almost never interpret the line as the translator in Birch's anthology does. Therefore, there must be some more profound reason for the translator's misreading of the line. Since both possible meanings of the two words are linguistically plausible in the context, what really counts in this case is not 
language, but culture: the meaning intended by the author can only be determined with reference to the poem's cultural context. It has often been observed that in traditional Chinese society women's dealings with the male sex were generally characterized by bashfulness and reservation. They tended to remain aloof with, or even dread encounters with those who were superior to them in economic and social status. The translator of the poem in Cyril's anthology seems to have neglected this basic fact about the mentality of traditional Chinese women and allowed experience of his own culture to stear him toward the wrong choice from the two semantic possibilities provided by the source signs.

Another example comes from the 14th-century Chinese historical novel Sanguo Yanyi (The Romance of the Three Kingdoms). In the preface to his translation, M oss Roberts quotes what King Liu Bei says in Chapter 15 to comfort his sworn brother Zhang Fei, who is filled with deep remorse for having lost, through his own negligence, the city of Xuzhou along with Liu's two wives who were entrusted to his care by Liu: "Xiongdi ru shouzu, qizi ru yifu" (One's brothers are like his limbs while his wives are like his clothes) but misrepresents it as: "A brother is a limb. Wives and children are but clothes." In earlier vernacular Chinese (in which the novel was written), the expression qizi may be used either as a single word, denoting "wife," as is typical in modern usage; or as a phrase composed of two separate lexemes: qi "wife," and zi "children," as is the case in the 8th-century Chinese poet Du Fu's famous lines:

Quekan qizi chou he zai,

Manjuan shishu xi yu kuang.

[I gaze at my wife and children, all my grief forgotten.

And roll up my papers at random, wild with joy.]

Since qizi is used in both meanings in earlier vernacular Chinese (and in modern Chinese as well), neither dictionaries nor the linguistic context can help the translator decide what Liu Bei means by qizi. One would have to look to traditional Chinese values to really know what the prince has in mind when he uses the word. Women in old China held a very low social position compared to men, and were often no more than their husbands' servants or slaves. On the other hand, both men and women would have been overjoyed to bear a son because, according to Confucianism, which was the orthodox ethical guide for Chinese society over nearly 2,000 years, "of the three cardinal offenses against filial piety, having no male heir is the greatest." Chinese men of the era in question (and perhaps quite a number of their present-day counterparts) would have regarded their wives as clothes, but their sons as their darlings (Liu 1984: 234-235). This idea was probably somewhat alien to Roberts, who chose to decode qizi as "wife and children," based merely on his linguistic knowledge that this is the sense in which the lexical unit is most commonly used in ancient Chinese.

The second reason that cultural presuppositions merit attention from translators and teachers of foreign languages is that the communicative errors they give rise to are usually more covert and harder to detect than grammatical errors and may therefore cause serious misunderstanding in the target reader. For instance, a Westerner who meets up with a Chinese acquaintance in the street who has only a superficial knowledge of English may be puzzled or even made uncomfortable by the Chinese greeting "Where are you going?" perhaps even thinking that the inquirer is prying into his or her private life. 
Nida and Reyburn (1981: 2) point out that: "In fact, difficulties arising out of differences of culture constitute the most serious problems for translators and have produced the most far-reaching misunderstandings among readers." These difficulties exist largely because all translators work in some specific socio-cultural context. Inevitably, they will be under the sway of specific presuppositions proscribed by the culture in which they were brought up. To minimize the chance of misreading the original from their own cultural standpoint, translators need to be aware of and constantly alert for, among other things, the Vorstruktur ("pre-structure") imposed upon their consciousness by their cultural background. In order to avoid misreadings and misinterpretations of the source text, translators should make appropriate use of target-language resources to clarify any potentially misleading meanings linguistic signs could have in the target context.

In this paper I have focused almost exclusively on the negative facets of cultural misreading, for the simple reason that it has caused misunderstanding, hatred, and even bloodshed on too many occasions in human history. Before concluding my discussion, however, I should point out that, in some cases, cultural misreadings were indeed turned to good account in the receiving culture. M atteo Ricci (1552-1610), the pioneer Jesuit missionary who came to China in the late 16th century, for example, deliberately misread the Confucian notion of "H eaven," which refers largely to objective laws embodied by Nature, as something basically the same as the Christian conception of Dieu or God, a personified supernatural being and uniquely creative entity. Ricci's misreading brought the notion of God closer to the Chinese mind and thereby paved the way for widespread acceptance of Christianity in China over at least a century. Nietzsche's (1844-1900) philosophy, which was marked by an intense attack on the "slave morality" of Christianity, and by an ideal of Ü berermensch or "Superman" who would impose his will on the weak and worthless, was regarded as a precursor to Nazism. But in the first few decades of this century, when China was being torn apart by the invasions of the big powers, Nietzsche's "Superhuman" philosophy was misread by the leaders of the New Culture Movement (e.g. M ao Dun [1898-1981]) as a grave warning to weak nations. M ao Dun interpreted Nietzsche's argument for power and conquest as a call for weak nations to struggle against power and fight for their liberation if they did not wish to be enslaved. This creative misreading not only encouraged the national salvation movement in China at the turn of the century, but can also be seen as having enriched Nietzsche's philosophy (see Yue \& Le Pichon 1995: 111).

Today, as the human race moves into a new century in which different nations and cultures must learn to live peacefully on a planet which is becoming increasingly small and crowded, and in which science and information technologies provide more and more opportunities to know each other, purposeful cultural misreadings arising from good will are apparently not so desirable as they used to be. We need, perhaps more urgently than ever, a greater degree of cool-headed mutual understanding and mutual appreciation, and a good deal less ethnocentrism and prejudice. 


\section{NOTES}

1. In a strict sense, ecology is not cultural. It is included in the techno-economic system out of consideration for the way it interacts with the means of material production and consumption and the way it affects the very subsistence of the culture.

2. General history is the record of a society's people and events. M any would have a sustaining impact on the later stages of growth in the culture on which they left their footprints.

\section{REFERENCES}

Bassnet t, Susan \& André Lefevere (Eds) (1990): Translation, History and Culture, London, Pinter.

Benedict, Ruth (1959): Patterns of Culture, Boston, Houghton M ifflin.

Birch, Cyril et al. (Eds) (1980-1981): Anthology of Chinese Literature, 2 vols, New York, Grove, Vol. I.

Bock, Philip (1979): M odern Cultural Anthropology, 3rd ed., New York, Alfred \& Knopf.

Bul I ock, Alan \& Oliver St al l ybr ass (Eds) (1977): The Fontana Dictionary of M odern Thought, London, Fontana/Collins, xix $+684 \mathrm{pp}$.

Geert z, Clifford (1973): The Interpretations of Cultures, New York, Basic Books.

Jin, Kemu (1984): Bijiao Wenhua Lunji [Comparative Culture: an anthology], Beijing, Sanlian, $266 \mathrm{pp}$.

Ku h iw ezak, Piotr (1990): "Translation as Appropriation: The Case of Milan Kundera's The oke”, Translation, History and Culture, Susan Bassnett \& André Lefevere (Eds), London, Pinter, pp. 118-130.

Kunder a, Milan (1983): The Joke, London, Faber and Faber, [Chinese ed. Trans. Jing Kaixuan, 1991, Beijing, Writers, vii +325 pp.].

- - (1983): The Unbearable Lightness of Being [Chinese ed. Trans. Han Shaogong \& Han Gang, 1989, Shengming Zhong Buneng Chengshou zhi Qing, Beijing, Writers, 345 pp.].

Liu, Shaoming (1984): "Fangcun Yi Luan-Lun Yishi zhi Nan", Fanyi Yanjiu Lunwen Ji [An Anthology of Translation Studies], Eds. the Federation of Chinese Translators \& the Editorial Board of Zhongguo Fanyi [The Journal of Chinese Translation], 2 vols, Beijing, Waiyu Jiaoxue yu Yanjiu, Vol. I.

Nakamur a, Hajame (1981): Ways of Thinking of Eastern Peoples, Rev. Eng. trans. and ed. Philip Wiener, Honolulu, The University of Hawaii Press.

Nida, Eugene and William Reyburn (1981): Meaning Across Cultures, American Society of Missiology Series, no. 4, New York, Orbis Books, vi +90 pp.

Wang, Yuexi \& Wang En bao (Eds) (1994): 100 Chinese Classical Poems in English, Beijing, Beijing Institute of Languages Press, 515 pp.

Yue, Daiyun \& Alain Le Pichon (1995): Dujiaoshou yu Long [The Unicorn and the Dragon], Beijing, Peking University Press, $230 \mathrm{pp}$. 